\title{
GeoGebra Training for Making Mathematics Learning Media at SMPN 11 Depok
}

\author{
Roni Al Maududi, Rini Widia Putri Z, Purni Munah Hartuti \\ Universitas Indraprasta PGRI, Jakarta \\ Email: ronialmaududi@gmail.com
}

Received 10 September 2021 | Revised 12 October 2021 | Accepted 13 October 2021

\begin{abstract}
The purpose of this community service activities is to introduce and provide a GeoGebra training to Mathematics teachers at SMP Negeri 11 Depok. GeoGebra is a software that is used as a learning media in Geometry and Algebra as an innovation in learning Mathematics. So far, teachers are using simple tools only to explain about some topics in Mathematics to the students. The community service team will introduce and give a GeoGebra training. The methods that are used are training methods, accommodation, and discussion. The training is carried out by providing theories and practices to the teachers to operate the GeoGebra for Geometry and Algebra. The output target in this community service is the teachers can use GeoGebra as a learning media in Mathematics especially in Geometry and Algebra, GeoGebra module, and scientific articles.
\end{abstract}

Keywords: GeoGebra, Geometry, and Algebra.

\section{INTRODUCTION}

SMP Negeri 11 Depok is one of the State Junior High Schools in Depok which is located at Sukatani Permai Complex, Jl. Murbai, Sukatani, Tapos District, Depok City, West Java, Postal Code 16454, Tel. 021-8740148. The school was established in 1991, National School Number: 20229082, School Statistics Number: 201020504037, Accreditation A. The facilities and infrastructure at the school are adequate, there are 33 classrooms, playground, restroom, canteen, parking, office, mosques, fields, computer laboratories, science laboratories, libraries, LCD in every classroom and CCTV.

The results of observations of the community service team in the field, one of the problems obtained is that teachers have not utilized school facilities. Utilization of LCD facilities, especially in learning mathematics cannot be used optimally. This happens because of the limited use of information technology, especially in the delivery of mathematics material with learning media. Learning mathematics still uses conventional methods or lecture methods. The teacher writes the material on the blackboard and explains it then the students take notes and listen.

The teachers are not yet skilled in using computers, especially in operating a learning media, so they are more comfortable teaching in the conventional way. Therefore, it is necessary to 
provide training in a software GeoGebra learning media which is expected to improve the quality of teachers in learning mathematics, especially for geometry and algebra material.

Based on the observations of the community service team at partner schools, a problem was found that in learning geometry and algebra the teacher explained the material still using simple tools. This is the team's priority in carrying out community service by providing training using the software GeoGebra. The training provided is using software GeoGebra. The training materials to be implemented have been discussed based on the needs of the partners.

Based on the definition taken from the official GeoGebra website, GeoGebra is a software dynamic mathematics for all levels of education that combines geometry, algebra, worksheets, graphing, statistics, and calculus in one easy-to-use package. GeoGebra has become a leading provider of software math which is dynamic in supporting science, technology, engineering, and mathematics (STEM) education and teaching and learning innovation around the world.

GeoGebra has several advantages over other math software, including:

1. Geometry, algebra, and worksheets are fully dynamic.

2. Has an easy-to-use interface (user friendly interface) with advanced and powerful features.

3. Available in many languages in the world including Indonesian.

4. Have an open source license, in other words, it does not require a paid or free license to use it.

According to (Syahbana, 2016) "GeoGebra is a dynamic program that has facilities for visualizing or demonstrating mathematical concepts as well as a tool for constructing mathematical concepts."

According to (Hohenwarter \& Hohenwarter, 2008) quoted by (Syahbana, 2016), GeoGebra is a computer program to teach mathematics, especially geometry and algebra. This program is free to use and can be downloaded from www.geogebra.com/download. This GeoGebra program is very well known, so it is often visited and has been used by millions of people around the world, both by students, students, teachers, lecturers, and those who have an interest in using it.

Some of the benefits of the GeoGebra program in learning mathematics are as follows (Rahadyan et al, 2018):

a) Can produce geometric paintings quickly and accurately, even complex ones.

b) The existence of animation facilities and manipulation movements that can provide a visual experience in understanding geometric concepts.

c) Can be used as feedback/evaluation material to ensure that the geometric painting that has been made is correct.

d) Make it easier to investigate or show the properties that apply to a geometric object.

Some of the problems the community service team found at SMP Negeri 11 Depok in geometry and algebra are:

1. Utilization of LCD facilities that are not optimal, teachers still use conventional methods in learning geometry and algebra material. 
2. Teachers are not familiar with software as a medium for learning geometry and algebra materials to streamline learning time.

Those are the team's priority in carrying out community service by providing training using the software GeoGebra. The training provided is using software GeoGebra. The training materials to be implemented have been discussed based on the needs of the partners.

\section{METHODS}

This community service was carried out at SMP Negeri 11 Depok, Depok City, West Java Province from March to August 2021. The methods used were training, mentoring, and discussion methods. The training is carried out by delivering material and practice by teachers in the operation of software GeoGebra for geometry and algebra material.

The stages of planning community service activities, namely (Nur, 2016):

1. The first stage is the preparation stage.

The implementation team visits partners first to conduct an analysis of the conditions of partners, participants who will be given training, and prepare plans for activities to be carried out.

2. The second stage, namely the implementation stage.

The implementation team held training software Geometry, then the teachers did practice for geometry and algebra material.

3. The third stage, namely the evaluation stage.

Evaluation of the process during the preparation stage until the implementation of community service. This evaluation stage includes an enthusiastic evaluation of the participants, the participants' skills in operating the software GeoGebra, and suggestions or criticisms in the implementation of training activities.

Community service partners welcome the service activities that will be carried out by the team. Some of the support provided by partners are:

1. Coordinate training participants consisting of mathematics teachers at SMP Negeri 11 Depok.

2. Provide time and place to carry out activities.

3. Participate in providing facilities and infrastructure that support the implementation of training activities.

\section{RESULTS AND DISCUSSION}

This community service activity begins with taking care of licensing to partner schools, namely SMP Negeri 11 Depok on March 8, 2021. Permits are given directly by the principal of community service partner schools. Due to the pandemic conditions and restrictions on social activities, so that there are no activities at school, the discussion about community service activities with prospective community service participants (Mathematics teachers at SMP Negeri 11 Depok) is carried out through chat with one of the Mathematics teachers using the Whatsapp application.

At the beginning of the activity the community service team proposed the implementation of community service activities to partners on Monday, March 15, 2021, but because the 
partners were having PTS (Middle Semester Assessment) activities so based on an agreement with the prospective community service participants, this activity was held on Wednesday, March 17, 2021 at community service partner schools, namely SMP Negeri 11 Depok.

This community service activity was held in 1 meeting with a duration of 4 hours and was divided into 3 sessions starting at 08.00 WIB and ending at 12.00 WIB on Wednesday, March 17, 2021. Before the first session started, this community service activity was opened directly by the SMP principal. Negeri 11 Depok Mr. Gesit Inderbuana, S. Pd. which then continued into the first session of community service activities.

In this first session, the community service material was delivered by Mrs. Purni Munah Hartuti. Before entering the delivery of material, described in advance about what are the advantages and disadvantages of GeoGebra to be used in this community service activity, coupled with installation of GeoGebra software on laptops of each participant and the distribution modules.

After GeoGebra is installed on each participant's laptop, then enter the presentation of material about the introduction of tools in GeoGebra and continue with explaining the use of GeoGebra to create graphs from points, make lines from known algebraic equations, make parallel or perpendicular lines, determine the point of intersection and the root of the equation of a linear or quadratic line. Next, go to the construction material for flat shapes, circles and squares (Dhoruri, 2012).

During the explanation, community service participants were given time to practice the material given using GeoGebra either by following the explanation from the presenter or using the module that was distributed at the beginning of the activity. Figure 1 shows GeoGebra software training activities at SMP Negeri 11 Depok first session.
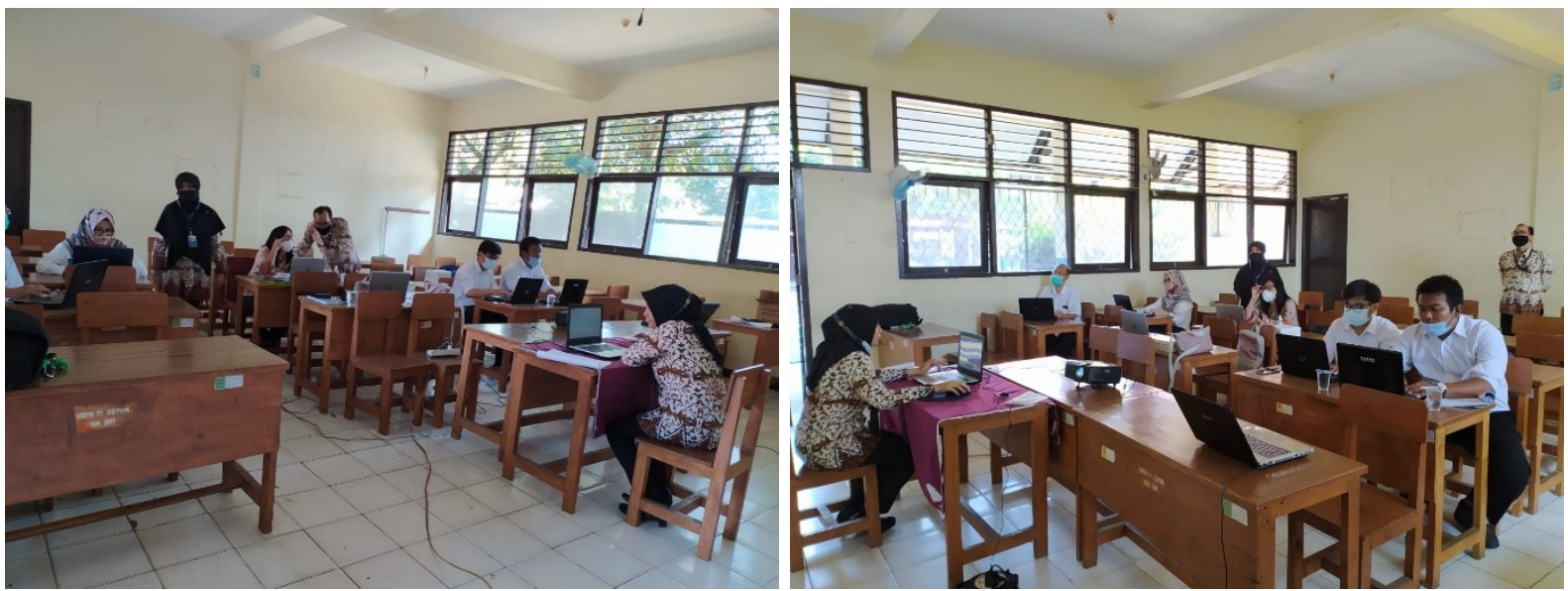

Figure 1. GeoGebra Software Training Activities at SMP Negeri 11 Depok First Session

In the second session, the community service material was delivered by Mr. Roni Al Maududi. In this second session, the material presented was about constructing flat shapes such as rectangles, triangles, rhombuses, kites, parallelograms, and trapezoids. Then proceed with an explanation of the construction of cubes, blocks, pyramids, cones, prisms, tubes, and spheres. 
As in the first session, community service participants were given time to practice the material that had been delivered by the presenters. Although some participants experienced problems in practicing the material presented, this could be overcome with the help of community service members who went around to provide assistance to participants who had difficulties. Figure 2 shows GeoGebra software training activities at SMP Negeri 11 Depok second session.

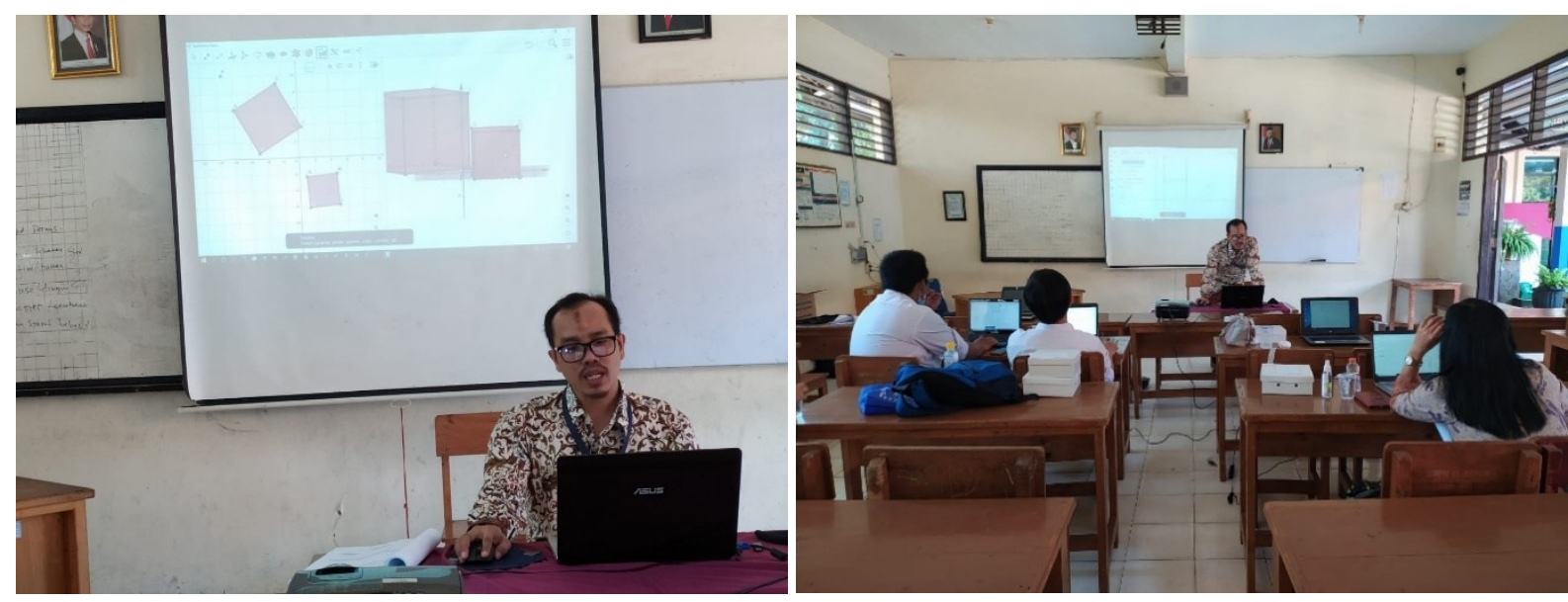

Figure 2. GeoGebra Software Training Activities at SMP Negeri 11 Depok Second Session

In the third session, Ms. Rini Widia Putri Z delivered community service material. In the last session, the material presented was on statistics, especially on the size of data concentration, data distribution, histograms, and frequency distribution tables. The next material is about the transformation of translation, reflection, rotation, and dilation.

As in previous sessions, in this session, community service participants were given time to practice the material presented either through the module or directly following the explanation from the presenter.

Figure 3 shows GeoGebra software training activities at SMP Negeri 11 Depok third session. The implementation of the training went smoothly without any significant obstacles because community service members could handle it well (Rohman, 2020).
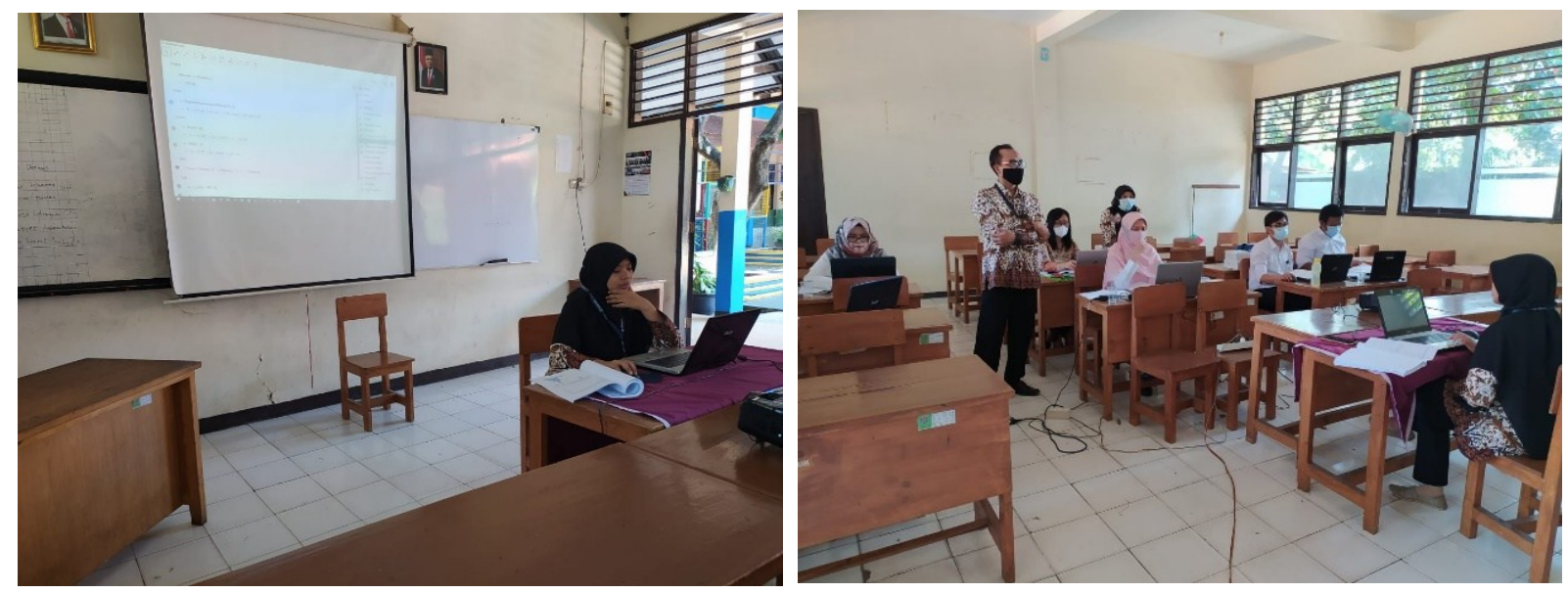

Figure 3. GeoGebra Software Training Activities at SMP Negeri 11 Depok Third Session 
During the implementation of the community service activities, all the Mathematics teachers participating in the community service seemed enthusiastic in participating in the training software GeoGebra, this was indicated by the many questions asked by the participants to the community service members who delivered the material in each session. Although some of the trainees had problems in carrying out the training provided, it did not reduce their interest in trying, even some of the trainees had previously used software GeoGebra to do their final assignment while still in college (Munarsih, 2018).

Some of the obstacles faced by community service participants are (Iswadi, 2011):

1. GeoGebra which has been installed on the participant's laptop several times has experienced errors when running. This may be because the version of the software installed GeoGebra is not compatible with the specifications of the laptops owned by community service participants.

2. Some of community service participants are not very familiar with using laptops and software, so they need a slightly longer explanation in carrying out the training provided.

3. Community service participants said that the time allotted to carry out the training was still insufficient, because some of training materials required a slightly deeper understanding.

4. The delivery of training materials by community service members was too fast, so participants who were not very familiar with using laptops and software had a little difficulty following the explanation of the material directly.

The discussion of the results of activities in terms of indicators of the success of the implementation of community service are as follows (Anggoro):

1. Almost all community service participants know the types and functions of GeoGebra tools and can use them according to the material provided, there are even some community service participants who are familiar with using the GeoGebra software.

2. Almost all community service participants are able to construct and practice the materials presented by the presenters, either directly when the presenters deliver it or by following the steps that have been written in the given module, although there are participants who need to be guided by community service members to practice the material presented. because they are not too familiar with using laptops and software, so it is a little difficult to follow directly the material presented by community service members

3. Almost all community service participants can use GeoGebra to create interactive learning media. This shows that almost all community service participants are able to use mathematics learning support software such as GeoGebra, to attract students' interest in learning.

4. Almost all community service participants can use GeoGebra to design practice questions or exams related to algebra, flat shapes, spatial shapes, statistics, and transformations, it is even possible that some community service participants can use GeoGebra to construct animations and math problems that complicated.

The evaluation of community service activities and the obstacles that occur in partner schools during the implementation of community service include (Maududi et al, 2020):

1. Before the community service activity started, the school had provided a special room for this community service activity, but due to miscommunication between community service participants and the school who did not participate in community service activities, the room that was originally provided for community service activities was used by the school 
for other activities. But this was resolved by moving the community service activities to another room.

2. Before starting the practice, the GeoGebra software installation was carried out by community service members to each participant's laptop. However, the GeoGebra application file brought by community service members only supports installation on the Windows operating system platform, while there are community service participants who use laptops with the MacOS operating system platform, so they cannot install GeoGebra software on the laptop. This was then overcome by borrowing a laptop owned by the school with the Windows operating system platform.

3. The explanation from the speaker was too fast, so there were some community service participants who had difficulty in practicing the material presented. But this can be overcome because community service members who go around quickly help community service participants who are having difficulties.

\section{CONCLUSION}

The conclusions that can be drawn based on the community service activities that have been carried out are as follows:

1. Community service participants are familiar with GeoGebra as one of software the supporting for learning Mathematics.

2. Community service participants are able to construct and create learning media using GeoGebra properly and with accurate and precise sizes and shapes

3. Community service participants can make practice questions and exams related to the construction of flat shapes or spaces with GeoGebra easier

4. Community service participants are able to present material with the help of GeoGebra media in learning Mathematics.

\section{LIST OF REFERENCES}

Anggoro, O. A. Y., \& Si, M. (n.d.). GeoGebra Untuk Geometri Transformasi. 2-6.

Dhoruri, A., Nugroho RS, E., \& Lestari, D. (2012). Pelatihan geogebra dalam pembelajaran matematika.

Hohenwarter, M., \& Hohenwarter, J. (2008). GeoGebra Help. 1-70.

Iswadi, H. (2011). Pengenalan Geogebra. Seminar Internal Departemen MIPA, September, 1-14. http://repository.ubaya.ac.id/187/1/hazrul_Pengenalan Geogebra_2011.pdf

Maududi, R. Al, Hikmah, R., \& Rejeki, S. (2020). Pelatihan Software Geogebra dalam Pembelajaran Geometri Bangun Datar Matematika di SMP PGRI dan SMPN 1 Cibinong. Jurnal PKM Pengabdian Kepada Masyarakat, 03(03), 295-300.

Munarsih, E. (2018). Sosialisasi Penggunaan Software Geogebra Pada Siswa Madrasah Aliyah Muqimussunah Palembang. Jurnal Abdimas Mandiri, 2(2), 127-130. https://doi.org/10.36982/jam.v2i2.534

Nur, I. M. (2016). Pemanfaatan Program Geogebra dalam Pembelajaran Matematika. Jurnal Matematika Dan Pendidikan Matematika, 5(1), 10-19. https://doi.org/10.1038/oncsis.2016.1

Rahadyan, A., Hartuti, P. M., \& Awaludin, A. A. R. (2018). Penggunaan Aplikasi Geogebra dalam Pembelajaran Matematika di Sekolah Menengah Pertama. Jurnal PkM Pengabdian 
Kepada Masyarakat, 1(01), 11. https://doi.org/10.30998/jurnalpkm.v1i01.2356

Rohman, M. F. (2020). Panduan Penggunaan Geogebra. 1-31. https://samuel07ben.files.wordpress.com/2013/02/panduan-geogebra.pdf

Syahbana, A. (2016). Belajar Menguasai GeoGebra (Program Aplikasi Pembelajaran Matematika). 